\title{
PREFERENSI KONSUMEN TERHADAP PEMBELIAN KERUPUK IKAN DI KOTA SINTANG
}

\author{
TRI WAHYUNI ${ }^{(1)}$, NURLIZA ${ }^{(2)}$, DEWI KURNIATI ${ }^{(2)}$ \\ 1) Alumni Magister Manajemen Agribisnis Fakultas Pertanian Universitas \\ Tanjungpura Pontianak. \\ 2) Staf Pengajar Fakultas Pertanian Universitas Tanjungpura Pontianak
}

\begin{abstract}
ABSTRAK
This study aims to determine consumer preferences of fish crackers product in Sintang city, and to determine which attributes are most considered by consumers.Attributes of the product that were analyzed in this study is the flavor, packaging, price, location, shape, color, and thickness. The sampling technique in this research is non probability sampling, by conducting interviews with 150 respondents which were analyzed using SPSS 17.0 software with conjoint method. From the seven attributes of fish crackers, the most preferable attributes as the consumer's consideration, sequentially are the price attributes, flavor, packaging, location of purchasing the fish crackers, fish crackers shapes, colors and the last one is the thickness of the fish crackers.

Keywords: Consumer Preferences, considered attributes, fish crackers, conjoint analysis.
\end{abstract}

\section{PENDAHULUAN}

Produk olahan perikanan yang dihasilkan di Kalimantan Barat beraneka ragam, baik hasil perikanan laut, budidaya, maupun perariran umum. Kota Sintang merupakan daerah di Kalimantan Barat yang menghasilkan produk perikananair tawar, baik berupa ikan segar maupun produk olahannya. Kerupuk ikan mempunyai rasa gurih yang khas dari ikan sungai. Kerupuk ikan terbuat dari bahan baku berupa ikan segar, bisa dibuat dari ikan Belida, ikan Toman, Ikan Gabus, ikan Lele dan Ikan lainnya atau biasa di kenal oleh masyarakat setempat dengan nama Ikan Bauk (ikan kecil-kecil). Di kota Sintang banyak dijumpai produk kerupuk ikan dengan merk dagang dan kemasan yang berbeda, namun kerupuk ikan hanya memiliki dua varian rasa. Oleh karena itu untuk dapat terus bersaing di pasaran maka dirasa perlu untuk dilakukan preferensi konsumen terhadap pembelian kerupuk ikan di kota Sintang. Berdasarkan latar belakang dan permasalahan yang mendasari penelitian ini, maka tujuan penelitian adalahuntuk mengetahui preferensi konsumen terhadap atribut dan level atribut dalam pembelian kerupuk ikan.

\section{METODE PENELITIAN}

Penelitian ini dilakukan di kota Sintang yang merupakan sentra pemasaran produk olahan hasil perikanan salah satunya kerupuk ikan. Sampel yang diambil dalam penelitian ini adalah sebanyak 150 responden, Teknik pengambilan sampel dalam penelitian ini adalah non probability sampling. Penelitian ini menggunakan metode analisis konjoin dengan bantuan software SPPS 17.0. dalam analisis konjoinsebelum melakukan analisis data, data yang diproleh akan diuji dengan uji validitas dan reliabilitas terlebih dahulu. Uji validitas digunakan untuk mengukur 
sah atau valid tidaknya suatu kuesioner. Penelitian ini mempunyai 19 profil yang menjadi dasar pertanyaan yang diajukan kepada 150 responden. Perhitungan validitas atau corrected item-total correlation menunjukkan terdapat 19 profil atau pertanyaan yang diajukan kepada responden dalam penelitian ini adalah valid, Hal ini berdasarkan kriteria pengambilan keputusan yaitu $r_{\text {hitung }}>r_{\text {tabel }}$ dimana $r_{\text {tabel }}$ adalah 0.159 pada tingkat signifikan sebesar 5\%. Selanjutnya pada 19 profil atau pertanyaan tersebut diuji melalui perhitungan reliabilitas atau cronbach's alpha. Berdasarkan kriteria pengambilan keputusan dimana nilai cronbach's alpha> 0,6yaitu 0,838 > 0,6 sehingga dari 19 profil atau pertanyaan tersebut dinyatakan reliabel.

Atribut yang digunakan dalam analisis konjoin terkait preferensi konsumen terhadap produk kerupuk ikan adalah rasa dengan level atribut gurih dan gurih pedas.Kemasan dengan level atribut kemasan bemerk, kemasan tanpa merk dan kiloan. Harga dengan level atribut Rp. 20.000-30.000 per kg, > Rp. 30.000-50.000, >Rp. 50.000. tempat dengan level atribut pasar tradisional, supermarket, toko oleh-oleh. Bentuk dengan level atribut bulat besar, bulat kecil dan berbentuk buah anggur. Warna dengan level atribut coklat muda, cokelat tua, dan hijau merah. Ketebalan kerupuk dengan level atribut tebal dan tipis.

\section{HASIL DAN PEMBAHASAN Karakteristik Responden}

Konsumenkerupuk ikan di kota Sintang lebih didominasi kaum perempuan dengan jumlah responden 131 orang $(87 \%)$ dan 19 responden $(13 \%)$ untuk kaum laki - laki. Hal ini dikarenakan perempuan relatif lebih berperan penting dalam hal pengambilan keputusan pembelian di dalam rumah tangga. Konsumen produk Kerupuk Ikan di Kota Sintang yang paling banyak yaitu berusia antara 21-40 tahun dengan jumlah responden sebanyak 116 orang (77\%). Konsumen yang paling banyak adalah dengan tingkat pendidikkan SMA yaitu sebanyak 84 orang (56\%). Sedangkan jika dilihat dari jenis pekerjaan maka koinsumen kerupuk ikan yang paling banyak adalah responden yang bekerja sebagai pegawai/karyawan dengan pengeluaran per bulan sebesar Rp. 1.000.000 s/d Rp. 3.000.000.

\section{Sikap dan Tujuan Membeli}

Konsumen memiliki tujuan yang berbeda - beda dalam pembelian kerupuk ikan. Konsumen yang membeli untuk konsumsi sendiri lebih memilih rasa gurih pedas, kemasan bermerk, dengan harga Rp. 30.000-50.000, membeli di toko oleh-oleh dan supermarket, dengan bentuk kerupuk ikan bulat kecil berwarna cokelat muda dan kerupuk ikan yang tebal. Sedangkan konsumen yang membeli kerupuk ikan untuk oleh-oleh / buah tangan memilih rasa gurih pedas, kemasan bermerk, dengan harga Rp. >30.000-50.000, membeli di toko oleh-oleh, dengan bentuk kerupuk ikan bulat besar dan yang berbentuk buah, berwarna hijau merah dan cokelat muda, dan kerupuk ikan yang berbentuk tipis. Sedangkan konsumen yang membeli kerupuk ikan untuk keperluan rumah makan, katering ataupun untuk dijual kembali tentu saja memilih kerupuk ikan dengan rasa gurih, membeli secara kiloan, dengan harga Rp. 20.000-30.000, membeli di pasar tradisional, berwarna coklat tua dan memilih kerupuk ikan yang tebal. 


\section{Preferensi Konsumen Terhadap Atribut Produk (Importance factor)}

Uji Tingkat Kepentingan Relatif dalam Analisis Konjoin bertujuan untuk melihat atribut mana yang paling penting dibanding atribut lain nya. Kontribusi tiap atribut menunjukkan tingkat preferensi konsumen terhadap produk kerupuk ikan. Dapat dilihat pada gambar berikut:

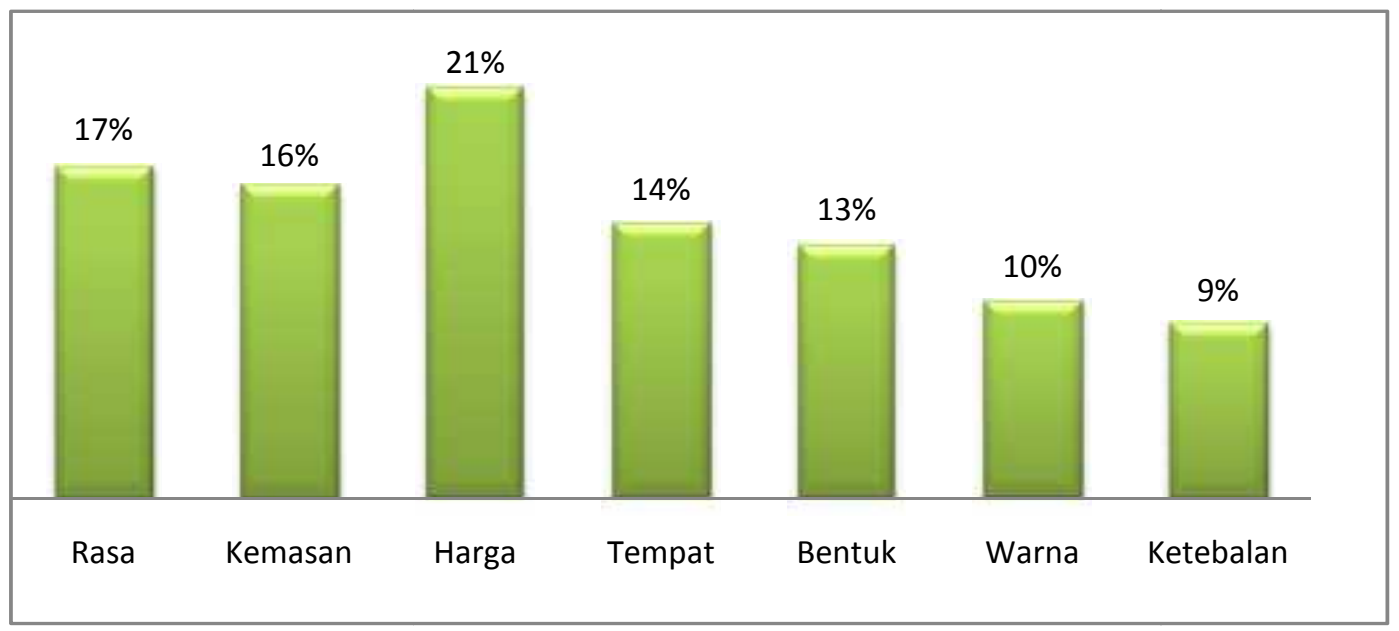

Gambar 4.1. Kontribusi Kepentingan Konsumen terhadap Atribut Produk Kerupuk Ikan

Gambar 4.1 diatas dapat dilihat bahwa dari tujuh atribut kerupuk ikan diatas menunjukkan bahwa tingkat kepentingan relative responden terhadap penilaian beberapa atribut kerupuk ikan memiliki nilai yang bervariatif.Adapun hal sangat di pertimbangkan atau dianggap penting oleh konsumen adalah atribut harga, rasa, kemasan, tempat pembelian, bentuk, warna dan ketebalan kerupuk.Dari tujuh atribut yang ada maka hal yang paling menjadi pertimbangan konsumen adalah harga, hal ini menggambarkan bahwa konsumen lebih memilih produk kerupuk ikan dengan harga yang paling murah jika di beri pilihan beberapa macam harga. Ada pun kerupuk ikan yang dijual di kota sintang ada beberapa macam harga yaitu kerupuk ikan dengan harga Rp.20.000-30.000, $>$ Rp.30.000-50.000, dan harga >Rp.50.000. dan harga yang paling banyak di pilih konsumen adalah harga Rp.20.000-30.000.Hasil penelitian ini di dukung oleh penelitian yang dilakukan oleh Nurheni (2011) mengenai kajian perilaku konsumen terhadap Strategi Pemasaran Teh Herbal di Kota Bogor, menjelaskan bahwa factor harga memilik hubungan yang positif dalam menentukan keputusan pembelian, dimana harga yang disukai oleh banyak kalangan adalah harga yang relatif terjangkau karena menjadi prioritas yang palin menonjol dikalangan masyarakat. Harga merupakan factor utama yang mempengaruhi konsumen (Kotler dan Amstrong, 2008)

Selanjutnya atribut yang menjadi pertimbangan konsumen adalah rasa yaitu sebesar $17 \%$ dimana kerupuk ikan hanya memiliki dua varian rasa yaitu gurih dan gurih pedas.Berdasarkan hasil penelitian, rasa kerupuk ikan yang paling di gemari adalah gurih pedas, rasa gurih pedas disini adalah rasa gurih kerupuk ikan dengan campuran sahang.Rasa merupakan atribut yang penting dalam keputusan pembelian.Hasil penelitian ini sesuai dengan sesuai dengan teori yang dinyatakan oleh Piggot, (1984) dalamAntimus (2016) bahwa penilaian seseorang terhadap suatu produk, rasa (flavour) menjadi lebih penting dari sifat lainnya ketika bahan makanan tersebut dirasa. 
Kemudian atribut yangdipertimbangkan konsumen adalah kemasan Yaitu sebesar $16 \%$, kemasan sebagai suatu pembungkus produk mempunyai peran yang penting, kemasan suatu produk harus dapat melindungi dan menjaga produk yang dikemas di dalamnya juga memberikan informasi tentang produk pada konsumen.Karena kualitas kemasan juga menentukan kepuasan responden terhadap produk yang dibelinya, dari kekuatan kemasan hingga keunikan kemasan suatu produk itu sendiri (Prasetyawati, 2010). Tujuan dari kemasan adalah sebagai pengaman produk untuk melindungi produk pada saat proses penjualan.kerupuk ikan pada umumnya masih dikemas secara sederhana, ada beberapa produk yang sudah dikemas dengan di lengkapi label/merk, ada yang dikemas dengan plastik tanpa merk dan ada juga yang di jual secara kiloan.

Kemudian atribut yang di pertimbangkan oleh konsumen adalah Tempat pembelian yaitu sebesar $14 \%$.konsumen lebih menyukai produk kerupuk ikan yang di jual di Toko Oleh-Oleh hal ini menunjukkan bahwa konsumen biasanya memilih kenyamanan tempat dalam berbelanja.Atribut tempat pembelian juga dianggap penting oleh konsumen, dimana atribut tempat pembelian menjadi pertimbangan keempat dalam memutuskan pembelian.Tempat juga menentukan bagaimana respon konsumen terhadap suatu produk, tempat yang strategis biasanya dipilih perusahaan untuk melakukan bisnisnya (Chiliya, Herbest, \& Lombard, 2009).

Atribut selanjutnya yang di pertimbangkan konsumen adalah bentuk kerupuk ikan yaitu $13 \%$ dimana kerupuk ikan yang dipasarkan memiliki bentuk bulat besar, bulat kecil dan ada yang berbentuk buah anggur. Atribut keenam yang di pertimbangkan konsumen dalam membeli kerupuk ikan adalah Warna kerupuk Ikan yaitu sebesar $10 \%$, warna kerupuk ikan ada beberapa yaitu cokelat muda, cokelat tua dan Hijau merah.

Selanjutnya yang menjadi pertimbangan terakhir konsumen dalam membeli kerupuk ikan adalah tingkat ketebalan kerupuk ikan yaitu 9\% hal ini di karenakan tingkat ketebalan pada kerupuk ikan tidak menunjukkan perbedaan yang terlalu mencolok sehingga konsumen tidak terlalu memperhatikan tingkat ketebalan pada saat memutuskan pembelian.

\section{Preferensi konsumen terhadap level atribut (utility)}

Preferensi yang diberikan responden terhadap setiap level atribut yang ada pada produk. Menurut Santoso (2010), pada dasarnya nilai utility adalah selisih antara rata-rata faktor tertentu dengan constantanya, jika selisih adalah positif, maka responden suka dengan stimuli produk tersebut dan jika selisih adalah negatif, maka responden kurang suka dengan stimuli produk tersebut. Menurut Sari (2010), faktor yang memiliki nilai utility negatif bukan berarti tidak memiliki suatu pengaruh melainkan tetap berpengaruh tetapi tidak memiliki sifat yang signifikan. Penjelasan untuk nilai kegunaan (utility estimate) tiap atribut kerupuk ikan dapat dilihat pada gambar berikut ini: 
Tabel 4.2 Preferensi konsumen terhadap level atribut

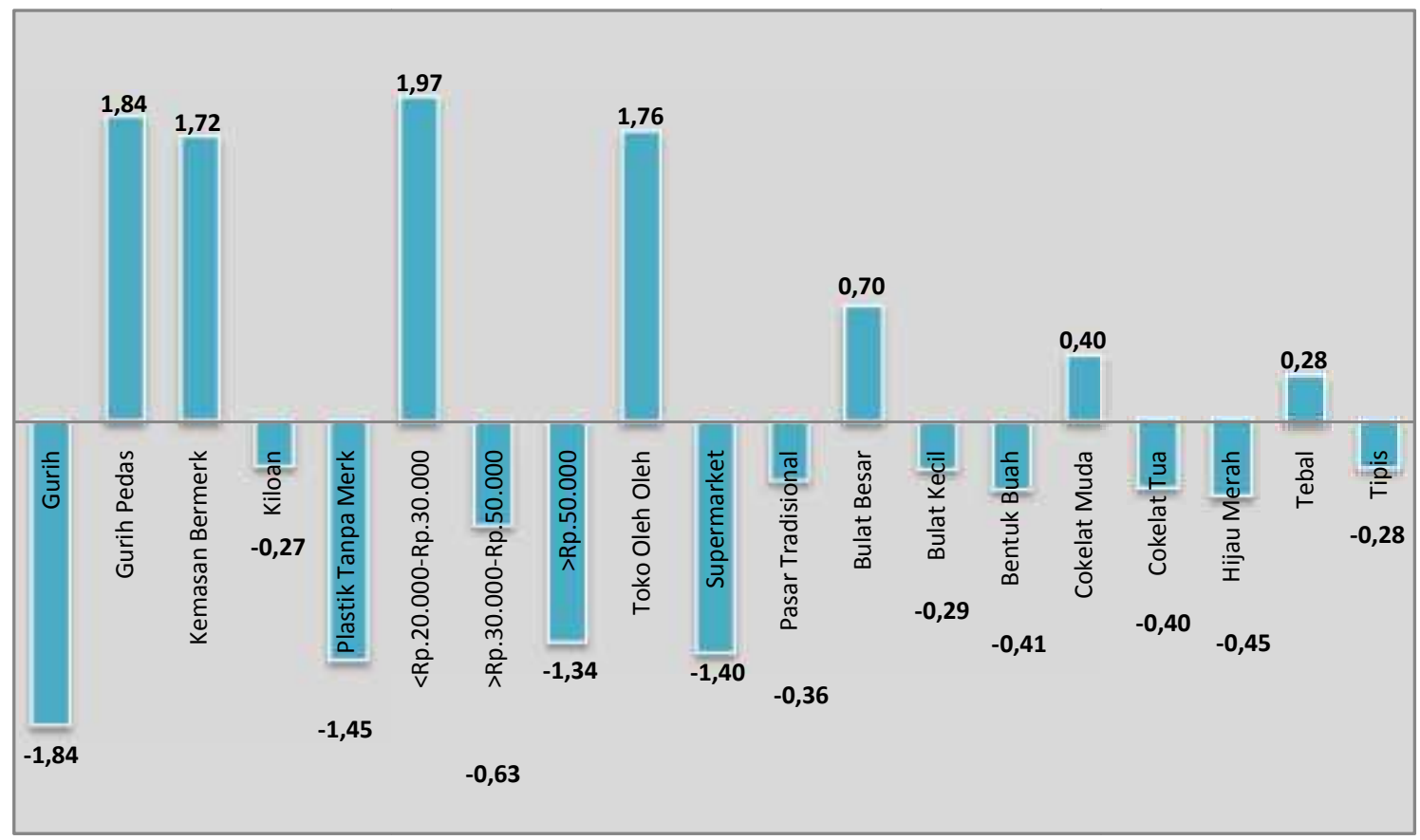

Sumber: data primer 2016

Gambar 4.2 diatas dapat menjelaskan bahwa pada atribut rasa kerupuk ikan konsumen lebih menyukai rasa gurih pedas bila dibandingkan dengan gurih biasa yaitu dengan nilai kegunaan positif 1,84 sedangkan pada rasa kerupuk ikan yang gurih mempunyai nilai -1.84 hal ini menunjukkan bahwa konsumen kurang menyukai kerupuk ikan dengan rasa gurih biasa.

Pada atribut kemasan kerupuk ikan bermerk memiliki nilai kegunaan positif sebesar 1,72 hal ini menunjukan bahwa konsumen lebih menyukai produk kerupuk ikan dengan kemasan bermerk. Sedangkan pada pilihan kerupuk ikan yang di jual dengan kemasan tanpa merk dan kerupuk ikan yang dijual dengan kiloan memiliki nilai kegunaan negatif yang menunjukkan bahwa konsumen kurang menyukai kerupuk ikan yang dijual dengan kemasan tanpa merk dan kerupuk ikan yang dijual secara kiloan. Namun pada beberapa konsumen ada yang lebih menyukai kerupuk ikan yang dijual secara kiloan, tergantung pada kebutuhan pembelian, konsumen yang membeli kerupuk ikan untuk keperluan rumah makan, kafe, dan katering lebih memilik kerupuk ikan yang dijual dengan kiloan.

Pada atribut harga konsumen lebih menyukai produk kerupuk ikan dengan harga <Rp.20.000-Rp.30.000 nilai kegunaan positif nya sebesar 1,97\%, Hal tersebut disebabkan pada umumnya semua responden menginginkan harga yang terjangkau dalam membeli dan memenuhi kebutuhan hidupnya (Cahyadi, Astuti, \& Anggraini, 2014).Sedangkan pada harga kerupuk ikan >Rp.30.000-50.000 mempunyai nilai kegunaan sebesar $-0,63$ dan pada harga $>$ Rp.50.000 mempunyai nilai kegunaan -1,34 hal ini menunjukkan bahwa konsumen kurang menyukai kerupuk ikan dengan harga >Rp.30.000-50.000 dan harga kerupuk ikan $>$ Rp.50.000. Namun konsumen yang membeli kerupuk ikan untuk konsumsi sendiri dan konsumen yang membeli kerupuk ikan sebagai buah tangan / oleholeh cenderung memilih kerupuk ikan dengan harga >Rp.30.000-50.000 dan 
kerupuk ikan dengan harga >Rp.50.000 karena dengan harga tersebut tentunya memiliki rasa dan kualitas yang lebih baik bila dibandingkan dengan kerupuk ikan yang dijual dengan harga $<$ Rp.20.000-Rp.30.000.

Pada atribut Tempat pembelian kerupuk ikan di toko oleh-oleh memiliki nilai kegunaan positif sebesar 1,76 hal ini menunjukkan bahwa konsumen lebih menyukai produk kerupuk ikan yang di jual di toko oleh-oleh. Sedangkan pada tempat pembelian kerupuk ikan di supermarket memiliki nilai kegunaan sebesar 1,40 dan pada pasar tradisional memiliki nilai kegunaan $-0,36$ hal ini menunjukkan bahwa konsumen kurang menyukai pembelian kerupuk ikan di supermarket dan pasar tradisional, namun konsumen yang membeli kerupuk ikan untuk keperluan rumah makan ataupun untuk dijual kembali akan lebih memilih untuk membeli kerupuk ikan di pasar tradisional dengan pertimbangan harga di pasar tradisional lebih murah dibandingkan dengan harga kerupuk ikan yang di jual di toko oleh-oleh dan juga supermarket.

Pada atribut Bentuk kerupuk ikan bulat besar mempunyai nilai kegunaan positif sebesar 0,70 hal ini menunjukkan bahwa konsumen lebih menyukai produk kerupuk ikan berbentuk bulat besar. Sedangkan pada kerupuk ikan dengan bentuk bulat kecil memiliki nilai kegunaan sebesar -0,29 dan pada kerupuk ikan yang berbentuk buah mempunyai nilai kegunaan sebesar -0,41 hal ini menunjukkan bahwa konsumen kurang menyukai bentuk bulat kecil dan bentuk anggur. Namun tentu saja bukan berarti kedua level atribut bentuk kerupuk ikan tersebut tidak memiliki suatu pengaruh terhadap pembelian karena pada beberapa konsumen memiliki pilihan yang berbeda pada level atribut bentuk kerupuk ikan tersebut, yaitu tergantung pada tujuan konsumen dalam membeli kerupuk ikan. Konsumen yang membeli untuk konsumsi sendiri biasanya lebih memilih kerupuk ikan dengan bentuk bulat kecil, tetapi pada waktu tertentu, misalnya pada hari raya konsumen biasanya lebih memilih kerupuk ikan dengan bentuk buah.

Pada atribut Warna, kerupuk ikan dengan warna cokelat muda mempunyai nilai kegunaan positif sebesar 0,40 hal ini menunjukkan bahwa konsumen lebih menyukai produk kerupuk ikan yang berwarna Coklat muda bila dibandingkan dengan kerupuk ikan yang berwarna cokelat tua maupun yang berwarna hijau merah. Pada level atribut warna kerupuk ikan yang berwarna cokelat tua memiliki nilai kegunaan $-0,40$ dan kerupuk ikan yang berwarna merah hijau memiliki nilai kegunaan $-0,45$ hal ini menunjukkan bahwa konsumen kurang menyukai kerupuk ikan dengan warna cokelat tua dan merah hijau. Konsumen menganggap kerupuk ikan dengan warna cokelat muda adalah kerupuk ikan yang terbuat dari ikan dengan kualitas terabaik.

Selanjutnya pada Atribut ketebalan 0,28 hal ini menunjukkan bahwa konsumen lebih menyukai kerupuk ikan yang tebal bila di bandingkan dengan kerupuk ikan yang tipis.Kerupuk ikan yang tipis memiliki nilai kegunaan sebesar 0,28 yang berarti bahwa konsumen kurang menyukai kerupuk ikan yang tipis. Konsumen berpendapat bahwa kerupuk ikan yang tebal lebih terasa ikan nya bila dibandingkan dengan kerupuk ikan yang tipis.

\section{KESIMPULAN}

Dari hasil penelitian diatas dapat di simpulkan bahwa harga produk merupakan atribut yang paling dominan atau di pertimbangkan serta memiliki nilai tertinggi dalam mempengaruhi preferensi konsumen dalam membeli produk 
kerupuk ikan, atribut selanjutnya yang dipertimbangkan adalah rasa kerupuk ikan, kemasan produk, tempat pembelian, bentuk kerupuk ikan, warna kerupuk ikan dan yang paling terakhir yang dipertimbangkan konsumen adalah tingkat ketebalan kerupuk ikan.

Berdasarkan hasil penelitian dan kesimpulan diatas disarankan kepada produsen kerupuk ikan supaya dapat menciptakan produk kerupuk ikan dengan kombinasi produk yang paling disukai konsumen. Untuk mengatasi keterbatasan modal sebaiknya produsen kerupuk ikan mengemas produk dengan plastik kemasan yang lebih murah namun dikemas dengan warna yang lebih menarik. Produsen sebaiknya menggunakan bahan baku ikan yang murah namun di imbangi dengan bumbu yang lebih banyak agar produk kerupuk ikan tetap terasa gurih dan enak.Khususnya untuk instansi terkait, supaya dapat memberikan pembinaan kepada para UKM-UKM pengolahan kerupuk ikan sehingga para produsen kerupuk ikan dapat menghasilkan produk yang lebih baik lagi, mengemas dalam kemasan yang lebih menarik sehingga memiliki nilai jual yang tinggi.Diharapkan kepada penelitian selanjutnya dapat menganalisis hal lain yang berkaitan dengan produk kerupuk ikan misalnya melakukan penelitian tentang bauran pemasaran, pengembangan produk ataupun Strategi pemasaran kerupuk ikan di Kota Sintang.

\section{DAFTAR PUSTAKA}

Agung Sugih Putra Tri Wibowo, 2015. Analisis Preferensi Konsumen Dalam Membeli Mi Instan. Universitas Tanjungpura Pontianak.

Antimus, Simanjaya, 2016. Analisis Preferensi Konsumen Kopi Instan Kapal Api di Kota Pontianak.Universitas Tanjungpura Pontianak.

Cahyadi, A. B., Astuti, R., \& Anggraini, S. (2014). Analisis Pengaruh Marketing Mix Terhadap Keputusan Pembelian Susu Pasteurisasi KUD SAE Pujon Malang Menggunakan Partial Least Square. Skripsi. Malang: Jurusan Teknologi Industri Pertanian, Universitas Brawijaya.

Chiliya, N., Herbest, G., \& Lombard, M. R. (2009). The impact of marketing strategies on profitability of small grocery shops in South African townships. African Journal of Business Management, Vol. 3, 070-079.

Ganggas Prasidya, 2014. Analisis Preferensi Konumen Terhadap Produk Bakpia Djogja Dengan Metode Konjoin. Universitas Brawijaya, Malang.

Ghozali, Imam. 2011. Aplikasi Analisis Multivariate dengan Program IBM SPSS 19. Badan Penerbit Universitas Diponegoro. Semarang.

Husnia, Alfaini." Perilaku Konsumen dan Faktor-Faktor Yang Mempengaruhi Perilaku Konsumen". 25 Agustus 2015. blogspot.com/p/softskill.html.

Fransisca, Merdi. "Perilaku K onsumen" . 25 Agustus 2016. blogspot.com/

Isni Yuniar Riska, 2012. Analisis Preferensi Konsumen Terhadap Buah Jeruk Lokal dan Buah Jeruk Impor di Kabupaten Kudus. Universitas Sebelas Maret, Surakarta.

Kalsum, Ummi. 2013. Analisis Preferensi Konsumen Dalam Membeli Rengginang Lorjuk di Kecamatan Kamal Bangkalan.Jurnal Agriekonomika Vol. 2, No. 2, Oktober 2013.

Kotler, Philip. 2000. Manajemen Pemasaran, Analisis Perencanaan, Pengendalian. Prentice Hall, Edisi Bahasa Indonesia. Penerbit Salemba Empat. Jakarta 
Kotler, Philip. 2006. Marketing Management. Twelfth Edition.Prentice Hall. Kotler and Armstrong. 2008. Prinsip-Prinsip Pemasaran-Terjemahan. Jilid 1. Edisi Kedua Belas. Penerbit Erlangga.

Nazir, M. 2005. Metode Penelitian, Cetakan Keenam. Ghalia Indonesia: Jakarta.

Nurheni S. Palupi, E. Srivishnu Herlambang, Musa Hubels. 2011. Kajian Perilaku Konsumen Terhadap Strategi Pemasaran The Herbal di Kota Bogor.Jurnal Manajemen IKM Vol. 6 No.2. Bogor. Institut Pertanian Bogor.

Prof. DR. Sugiyono . 2004. Metode Penelitian Bisnis, Cetakan ke tujuh. Penerbit Alfabeta.

Prasetyawati, N. (2010). Analiss Faktor Marketing Mix Terhadap Keputusan Pembelian Susu Formula Balita Pada Pasar Swalayan di Kota Yogyakarta. Surakarta: Fakultas Pertanian, Universitas Sebelas Maret.

Santoso, S. 2014. Statistik Multivariat, edisi Revisi Konsep dan Aplikasi dengan SPSS. Penerbit PT. Elex Media Komputindo.

Santoso, S. 2010. Statistik Multivariat. PT Elex Media Komputindo. Jakarta.

Sari, D. 2010. Analisis Tingkat Kepentingan Atribut Perpustakaan Berbasis Riset Melalui Metode Conjoint Analysis (Studi Kasus Di Universitas Diponegoro).Jurnal Teknik Industri Vol V, No 2.

Siswanto, Felix. 2009. Analisis Preferensi Konsumen Untuk Pengembangan Produk Wafer Samba Di Jakarta.

Siti Rosipah, 2013. Preferensi Konsumen Terhadap Pancake Dari Tepung Sukun.Agrointek, vol 7 No 1, Jakarta.

Supranto, J. 2004. Ekonometri.Ghalia Indonesia: Jakarta 